\title{
FINISHING PRODUCT FOR IMPROVING ANTIFUNGAL PROPERTIES OF LEATHER
}

\author{
Olga NICULESCU1* ${ }^{*}$, Dana Corina DESELNICU ${ }^{2}$, Mihai GEORGESCU1 ${ }^{1}$, Mihaela NIJUICĂ ${ }^{1}$ \\ ${ }^{1}$ INCDTP - Division Leather and Footwear Research Institute, 93 Ion Minulescu St., Sector 3, Bucharest, Romania \\ ${ }^{2}$ Politehnica University of Bucharest, 313 Splaiul Independentei, 060042, Bucharest, Romania
}

Received: 19.02.2017

Accepted: 13.03.2017

https://doi.org/10.24264/Ifj.17.1.4

FINISHING PRODUCT FOR IMPROVING ANTIFUNGAL PROPERTIES OF LEATHER

ABSTRACT. Some biocides used in the leather industry have a certain toxicity and are prohibited by the directives in force. A product with antifungal properties containing coriander essential oil was tested as finishing auxiliary for bovine shoe upper leather. The paper presents the results obtained in leather finishing using the new product AF-C and evaluation of its antifungal activity against Aspergillus niger strain. For maximum efficiency, the concentration of AF-C antifungal product must not decrease below $65 \%$ in the final dressing for leather finishing. KEY WORDS: leather, finishing, coriander essential oil, antifungal product

\section{PRODUS DE FINISARE PENTRU ÎMBUNĂTĂTIREA PROPRIETĂTILOR ANTIFUNGICE ALE PIEILOR}

REZUMAT. Unele biocide utilizate în industria de pielărie au o anumită toxicitate şi sunt interzise prin directivele în vigoare. S-a testat un produs cu proprietăţi antifungice care conţine ulei esenţial de coriandru în vederea utilizării ca auxiliar de finisare a pieilor bovine pentru feţe încălţăminte. Lucrarea prezintă rezultatele obţinute la utilizarea noului produs antifungic AF-C la finisarea pielii şi evaluarea activităţii antifungice împotriva tulpinii Aspergillus niger. Pentru eficienţă maximă, concentraţia de produs antifungic nu trebuie să scadă sub 65\% în apretul final pentru finisarea pielii.

CUVINTE CHEIE: piele, finisare, ulei esenţial de coriandru, produs antifungic

\section{PRODUIT POUR LA FINITION DU CUIR POUR AMÉLIORER SON PROPRIÉTÉ ANTIFONGIQUE}

RÉSUMÉ. Certains biocides utilisés dans l'industrie du cuir ont une certaine toxicité et sont interdites par les directives en vigueur. On a testé un produit aux propriétés antifongiques contenant d'huile essentielle de coriandre afin de l'utiliser comme auxiliaire de finition pour les cuirs bovins pour chaussures. L'article présente les résultats obtenus par l'utilisation d'un nouveau produit antifongique de finition, AF-C, et l'évaluation de l'activité antifongique contre Aspergillus niger. Pour une efficacité maximale, la concentration de produit antifongique ne devrait pas tomber en dessous de $65 \%$ dans la composition finale pour la finition du cuir.

MOTS-CLÉS: cuir, finition, huile essentielle de coriandre, produit antifongique

\section{INTRODUCTION}

Biological factors (fungi, bacteria) may damage leather and leather items by degradation of the grain (stains, matting, etc.). The cost of raw materials for leather production is significant. So, the preservation of stock is still fundamental to good quality control and making a living for tanners. Yet biocides by their very nature are environmentally unfriendly. However, help may be at hand, with research into new ecofriendly brands of bacterial control [1].

Biocides based on beta-naphthol, benzothiazole and sulfone derivatives, organic sulfur compounds, etc. used in the leather industry have a certain toxicity to humans and the environment, some of which are prohibited by the directives in force, i.e. pentachlorophenol, polyhalogenated phenolic compounds [2-5].

Many studies were aimed at replacing potentially hazardous substances used in the processing of hides, skins and furs:

- Synthesis of new classes of biocides based on derivatives of 2-amino-benzothiazole-6substituted with methyl, methoxy, chloro, nitro, modified chemically by sulphonation [6] and used in cattle leather processing [7] which have shown to be effective against Aspergillus niger species, but not against the Trichoderma viride species;

- Synthesis of new classes of tanning agents to replace chromium in tanning hides and furs [8-15].

Several studies have been conducted on the use of natural products derived from plants for the treatment of leather and fur:

Bayramoglu et al. [16, 17] from Ege University in Turkey used Origanum species to extract essential oils from plants through steam distillation process. It has been found that utilization of the essential

Correspondence to: Olga NICULESCU, INCDTP - Division Leather and Footwear Research Institute, 93 lon Minulescu St., Sector 3, Bucharest, Romania, email: o_niculescu@yahoo.com 
oil of Origanum minutiflorum during pickling has antifungal activity and that its effect is improved with increasing concentration. As a result of this study, it was found that the wet blue leather specimens treated with $1 \%$ Origanum sp. essential oil showed antibacterial effect on Gram-positive bacteria. Origanum minutiflorum essential oil had an antifungal effect on wet blue. The bacteria are more resistant to the essential oils than yeasts and moulds. A concentration of $21 \%$ relative to the float of the essential oils of oregano from three different species and fennel oil was tested for their antimicrobial activity along with $7-25 \%$ of phenol and 4-chloro-3-methyl-phenol as a commercial bactericide commonly used in the leather industry. The results showed that the three essential oils of oregano had a much stronger bactericidal activity than the commercial product and may find use as antibacterial agents in the leather industry.

- Use of essential oils in finishing leather and fur [18-20];

- Use of essential oils to stop the growth of fungi [21].

Essential oils from aromatic and medicinal plants have been known to possess potential as natural agents for leather preservation, including antibacterial and antifungal; in fact, many essential oils have been qualified as natural biocides and offered as potential substitutes of synthetic biocides in specific steps of leather processing. Many studies revealed utilization of essential oils for leather and leather objects protection against fungi [22-32].

Coriander (Coriandrum sativum L.) is an annual herbaceous plant originally from the Mediterranean and Middle Eastern regions, cultivated for its culinary, aromatic and medicinal use. This plant is of economic importance since it has been used as a flavoring agent in food products, perfumes, cosmetics and drugs. This culinary and medicinal plant is widely distributed and mainly cultivated for the seeds which contain an essential oil (ranges between $0.3 \%$ and $1.1 \%$ ) [33]. The essential oil and various extracts from coriander have been shown to possess antibacterial, antidiabetic, anticancerous, antimutagenic, antioxidant and free radical scavenging activities [34, 35]. In addition to its culinary value, coriander is known for its wide range of healing properties.

Coriander essential oil contains $60-70 \%$ d-linalool (or coriandrol, geraniol, cimol, pinene, terpinene, phellandrene, dipentene, petroselinic acid, etc.), $15-20 \%$ lipids, $10 \%$ starch, $4-5 \%$ mineral substances, pectins, etc. [36, 37]. Coriander essential oil has bactericidal and fungicidal properties [38-41].

Coriander seed essential oil is high in linalool. European oils show monoterpene hydrocarbon content between 16 to $30 \%$, linalool 60 to $75 \%$, whereas a considerable amount of other oxygenated monoterpenes is also present. The main monoterpene hydrocarbon components detected in these oils are $\gamma$-terpinene (up to $10 \%)$, and limonene, $p$-cymene, $\alpha$-pinene up to $7 \%$ each. The most prominent non-linalool oxygenated monoterpenes reported are geranyl acetate up to levels of $5 \%$, borneol up to $7 \%$, camphor and geranial up to $4 \%$ each and geraniol up to $2 \%$ [42].

Linalool is a tertiary alcohol isomer of geraniol and nerol, containing an asymmetrical carbon atom; it is found in nature preponderantly in isopropylidene form; it is a component of over 200 essential oils of various origins (herbs, leaves, flowers, fruits, wood); the dextrorotatory form $(+)$ was isolated from coriander essential oil and is found in a proportion of $60-70 \%$.<smiles>C=CC(C)(O)CCC=C(C)C</smiles><smiles>C=CC(C)(O)CCC=C(C)C</smiles>

Figure 1. Linalool structure

A new leather finishing auxiliary with antifungal properties (AF-C) was prepared based on beeswax, lanolin, ethanol and lauryl alcohol ethoxylated with 7 moles of ethylene oxide and coriander essential oil $[18,19]$.

The aims of this study are as follows: (i) to study utilization of the new product, AF-C, in leather finishing; (ii) to evaluate its antifungal activity.

\section{EXPERIMENTAL \\ Materials}

The chrome tanned bovine leathers, finished and crust for shoe upper: 1.2-1.4 mm 
thickness; brown; obtained in the facilities of INCDTP - Division Leather and Footwear Research Institute Bucharest, Romania.

Auxiliary materials for leather finishing from TFL Company, Germany.

Roda Casicolor Brown R: viscous and homogenous fluid, dry substance $38 \%$; $\mathrm{pH}$ (10\% solution) 7; ash - 28\%;

Roda wax MONO: dry substance $36.87 \%$; $\mathrm{pH}$ ( $10 \%$ solution) 4.2; Ford cup viscosity $\$ 4,12$; kinematic viscosity $8.97 \mathrm{cSt}$; density $0.957 \mathrm{~g} / \mathrm{cm}^{3}$; Roda-cryl 87: dry substance $34.50 \% ; \mathrm{pH}$ (10\% solution) 6.0; Ford cup viscosity $\$ 4,14$; density $1.025 \mathrm{~g} / \mathrm{cm}^{3}$;

Roda-pure 302, polyurethane binder for ground coat: dry substance $30.87 \%$; $\mathrm{pH}$ (10\% solution) 7.5; Ford cup viscosity $\Phi 4,15$; density $1.076 \mathrm{~g} / \mathrm{cm}^{3}$;

Roda-pure 5011, polyurethane binder: dry substance $40 \%$; pH (10\% solution) 5.5; Ford cup viscosity $\Phi 47$; density $1.053 \mathrm{~g} / \mathrm{cm}^{3}$;

Product AF-C with antifungal properties, prepared from coriander essential oil, beeswax, lanolin, ethanol and lauryl alcohol ethoxylated with 7 moles of ethylene oxide $[18,19]$ with the following characteristics: dry substance $12 \% ; \mathrm{pH}$ (10\% solution) 4.5 ; density $0.820 \mathrm{~g} / \mathrm{cm}^{3}$.

\section{Methods}

Chemical characteristics of shoe upper leather were determined according to the following standards:

- SR EN ISO 4684:2006; Leather - Chemical tests - Determination of volatile matter;
- EN ISO 4048: 2008 - Determination of matter soluble in dichloromethane and free fatty acid content;

- SR EN ISO 5398:2008 - Leather Determination of chromic oxide content; Part 1: Quantification by titration;

- EN ISO 4045:2008 - Determination of $\mathrm{pH}$ and difference figure;

- SR EN ISO 11640:2002 - Strength to dry and wet abrasion (1-5 ranking);

- $\quad$ SR EN ISO 5402:2012 - Resistance to repeated bending, number of flexions.

Antifungal activity against Aspergillus niger: The tests were made following standard ASTM D 4576-2013, Standard Test Method for Mold Growth Resistance of Wet Blue.

Petri dishes were placed in thermohygrostat at $30^{\circ} \mathrm{C}$ temperature and were observed and evaluated after $3,7,14,21$ and 28 days.

Optical microscopy images were captured using a Leica stereomicroscope S8APO model with optic fiber cold light source, L2, with three levels of intensity and magnification 40X.

\section{Obtaining Bovine Shoe Upper Leather}

Two series of experiments were performed in order to obtain cattle shoe upper leather using finishing auxiliary with antifungal properties (AF-C):

- Series I prepared with technology presented in Table 1 and with different quantities of product AF-C according to Table 2: Samples AF-1; AF-2; AF-3; control sample - M1;

Table 1: Finishing technology for bovine shoe upper leather

\begin{tabular}{ll}
\hline \multicolumn{1}{c}{ Operation } & \multicolumn{1}{c}{ Composition of dispersion/Method of application } \\
\hline & $60-80 \mathrm{~g} / \mathrm{L}$ Roda Casicolor Brown \\
& $20 \mathrm{~g} / \mathrm{L}$ Roda wax MONO \\
Basecoat (Applying Dispersion I) & $125 \mathrm{~g} / \mathrm{L}$ Roda-cryl 87 \\
& $125 \mathrm{~g} / \mathrm{L}$ Roda-pure 302 \\
& $650-670 \mathrm{~g} / \mathrm{L}$ water \\
& Application by spraying 2 times \\
& Hydraulic press using mirror or steam plate, parameters: \\
& $\quad-$ temperature $-50-60^{\circ} \mathrm{C}$ \\
Intermediate pressing & $\quad$ - pressure $-50-100$ bar \\
& By spraying 2-3 times \\
Applying Dispersion I & Applying Dispersion II (see Table 2) \\
Antifungal treatment / fixing & Spraying 2 times \\
& Hydraulic press using mirror plate, parameters: \\
& - temperature $-70-80^{\circ} \mathrm{C}$ \\
Final pressing & pressure $-50-100$ bar
\end{tabular}


Table 2: Composition of dispersion II

\begin{tabular}{ccl}
\hline No. & Sample & Composition of dispersion II \\
\hline 1 & AF-1 & $1000 \mathrm{~g} / \mathrm{L}$ product AF-C \\
2 & AF-2 & $750 \mathrm{~g} / \mathrm{L}$ product AF-C \\
& & $250 \mathrm{~g} / \mathrm{L}$ RODA pur 5011 \\
& AF-3 & $650 \mathrm{~g} / \mathrm{L}$ product AF-C \\
3 & M1 Control & $700 \mathrm{~g} / \mathrm{L}$ RODA pur 5011 \\
& & $300 \mathrm{~g} / \mathrm{L}$ water \\
4 & AF-4 & $1000 \mathrm{~g} / \mathrm{L}$ product AF-C \\
5 & M2 Control & Not finished \\
\hline
\end{tabular}

- Series II in which only finishing auxiliary with antifungal properties AF-C was used for leather finishing according to Table 2: Samples AF-4; unfinished leather was used for control sample M2.

Product AF-C was compatible with the materials used in the final dressing. Leather from Experiment AF-1 was sticky after pressing.

AF-C product can be used as such in surface finishing of buffed bovine hides such as suede, buffo or nubuck to obtain a fatty/waxy feel and a better resistance to fungi of the dermal substrate.

\section{RESULTS AND DISCUSSION}

\section{Characterization of Leather Finishing}

Chemical characteristics of the leathers were determined in accordance with standard STAS 1619:1994: Leather for uppers and leather goods. Cattle skins tanned with chrome, grain finished. General technical conditions (Table 3).

Chemical and physical-mechanical characteristics of leather were within the limits specified in standard 1619:1994.

\section{Evaluation of Antifungal Effect of Leather Finished with AF-C Product}

The experiment examines how the growth of mold is influenced by existing treatment on the leather sample treated with biocides through mold resistance under simulated contamination.

Leather untreated with the AF-C product was used as a control: M1 - finished leather and $\mathrm{M} 2$ - not finished (crust) leather. Incubation duration was 28 days and fungal observations were performed at intervals of 7, 14, 21 and 28 days. Mold development on leather samples was evaluated by ranking according to the notation used in the standard method used: mark 0 indicates the absence of stems and a strong fungitoxic effect, and mark 5 indicates no fungitoxic effect, the mold covering the entire surface of the specimen.

Development of the Aspergillus niger strain on leather samples over time, i.e. macroscopic images of the samples are shown in Table 4.

Table 3: Chemical characteristics of bovine shoe upper leather

\begin{tabular}{lccccccc}
\hline \multicolumn{1}{c}{ Sample/Characteristic } & AF-1 & AF-2 & AF-3 & M 1 & AF-4 & M 2 & $\begin{array}{c}\text { STAS } \\
1619: 1994\end{array}$ \\
\hline $\begin{array}{l}\text { Volatile matter, \% } \\
\text { Extractibles, \% }\end{array}$ & 13.97 & 14.76 & 13.78 & 13.80 & 13.88 & 14.09 & $14-15$ \\
$\begin{array}{l}\text { The content of chromium } \\
\text { oxide, \% }\end{array}$ & 7.88 & 7.67 & 7.57 & 7.44 & 7.87 & 7.96 & Max. 8 \\
pH & 5.93 & 5.74 & 5.66 & 5.47 & 5.77 & 6.10 & Min. 3.5 \\
$\begin{array}{l}\text { Dry and wet abrasion } \\
\text { strength, rank }\end{array}$ & $5 / 4$ & $5 / 4$ & $5 / 4$ & $5 / 5$ & $5 / 4$ & $5 / 4$ & $5 / 4$ \\
$\begin{array}{l}\text { Resistance to repeated } \\
\text { bending, number of } \\
\text { flexions }\end{array}$ & $4 / 3$ & $4 / 3-4$ & $4 / 4$ & $5 / 5$ & $4 / 4$ & & \\
\hline
\end{tabular}


Table 4: Images of leather samples within Series I experiment

\begin{tabular}{|c|c|c|c|c|}
\hline Sample & 7 davs & 14 davs & 21 davs & 28 davs \\
\hline \multicolumn{5}{|l|}{ AF-1 } \\
\hline mark & 0 & 0 & 0 & 0 \\
\hline \multicolumn{5}{|l|}{ AF-2 } \\
\hline mark & 0 & 0 & 0 & 2 \\
\hline \multicolumn{5}{|l|}{ AF-3 } \\
\hline $\begin{array}{l}\text { mark } \\
\text { Control }\end{array}$ & 2 & 2 & 4 & 4 \\
\hline \multicolumn{5}{|l|}{ M 1} \\
\hline mark & 4 & 5 & 5 & 5 \\
\hline
\end{tabular}

Table 5: Images of leather samples within Series II experiment

\begin{tabular}{|c|c|c|c|c|}
\hline Sample & 7 days & 14 days & 21 days & 28 days \\
\hline \multicolumn{5}{|l|}{ AF-4 } \\
\hline mark & 0 & 0 & 0 & 0 \\
\hline \multicolumn{5}{|l|}{ Control } \\
\hline \multicolumn{5}{|l|}{$\mathrm{M} 2$} \\
\hline mark & 4 & 5 & 5 & 5 \\
\hline
\end{tabular}

In the two series of experiments, the leather samples AF- 1 and AF-4 were the most resistant to mold, the samples did not develop fungi for 28 days - mark 0; the leather sample AF2 did not develop fungi for 21 days - mark 0 ; the leather sample AF3 developed fungi after 7 days - mark 2. It can be observed that the fungitoxic effect decreased with reduced quantities of AF-C used in the final dressing composition.

The negative control leather $\mathrm{M} 1$ and $\mathrm{M} 2$ (without product AF-C) already failed in the first week and received marks ranging between 4 after 7 days and 5 after 14 days.

Moisture content and $\mathrm{pH}$ of the leather have been reported as the main biotic factors affecting the fungal deterioration. In the present investigation, the volatile matter content and $\mathrm{pH}$ of leather ranged between 13.78 and $14.76 \%$, and between 4.5 and 6 , respectively. So, the fungal distribution on the samples was not influenced by their moisture content and $\mathrm{pH}$.

The finishing auxiliary with antifungal 
properties AF-C improved resistance of finished leather to biological factors (fungi). For maximum efficiency, the concentration of the antifungal product must not decrease below $65 \%$.

\section{CONCLUSIONS}

Results showed that the AF-C product containing coriander essential oil could be used as natural antifungal in leather finishing. The AF-C product can be used in surface treatment of bovine finished leather for shoe upper and in surface finishing of buffed bovine hides such as suede, buffo or nubuck to obtain a fatty/ waxy feel and a better resistance to fungi of the dermal substrate. The AF-C product improved resistance of finished leather to biological factors (fungi) and can complement treatment with biocides used to treat natural leather in wet processing operations. For maximum efficiency, the concentration of the antifungal product must not decrease below $65 \%$ in the final dressing for leather finishing.

\section{Acknowledgements}

This work was supported by ANCSI in the framework of "Nucleu" Program INOVA-TEXPEL, 2016-2017, project code PN 163402 06, contract 26N/2016.

\section{REFERENCES}

1. Lampard, G., Alternative Biocides - An Optimistic Future, Leather International, 2009, 211, 4795, 28.

2. Directive 2010/75/EU of the European Parliament and of the Council of 24 November 2010 on Industrial Emissions (Integrated Pollution Prevention and Control).

3. Deselnicu, D.C., European Policies for Products and their Relevance for the Footwear Sector (in Romanian), 2014, ISBN: 978-973-720-5551 , Agir Press.

4. Deselnicu, D.C., Vasilescu, A.M., Purcarea, A.A., Militaru, G., Sustainable Consumption and Production in the Footwear Sector, Leather and Footwear Journal, 2014, 14, 3, 159-180.

5. Deselnicu, V., Deselnicu, D.C., Vasilescu, A.M., Militaru, G., EU Policy for Sustainable Consumption and Production - EU Ecolabel for Footwear, Proceedings of the 5th International Conference on Advanced Materials and Systems ICAMS 2014, 23-25 October 2014, Bucharest, 641-646.
6. Jârlea, M.M., Mutlu, M.M., Bitlisli, B.O., Basaran, B., Adiguzel Zengin, A.C., Antifungal Compounds for Leather. Part I - Synthesis of Benzothiazoles Biocides for Bovine Leathers, Leather and Footwear Journal, 2009, 9, 2, 104-117.

7. Târlea, M.M., Mutlu, M.M., Macovescu, G., Radulescu, C.H., Adiguzel Zengin, A.C., Bitlisli, B.O., Basaran, B., Antifungal Compounds for Leather. Part II - Testing of Antifungal Activity on Bovine Leather, Leather and Footwear Journal, 2009, 9, 4, 284-295.

8. Crudu, M., Deselnicu, V., loannidis, I., Crudu, A., New Wet White Tanning Agents and Technology, Proceedings of the 4th International Conference on Advanced Materials and Systems, ICAMS 2012, 27-29 September 2012, Bucharest, 27-34.

9. Crudu, M., Deselnicu, V., Mutlu, M.M., Gulumser, G., Bitlisli, B.O., Basaran, B., Adiguzel Zengin, A.C., New Tanning Agents Based on Titanium and Zirconium, Proceedings of the 3rd International Conference on Advanced Materials and Systems ICAMS 2010, 16-18 September 2010, Bucharest, 27-32.

10. Crudu, M., Deselnicu, V., Rosca, I., Sutiman, D., Cailean, A., Ghiga, M., Bocu, V., Boca, N., Capac, D., Obtaining New Eco-Friendly Tanning Agents by Valorization of Wastes, Ecology \& Safety Symposium, June 2008, Sunny Beach, Bulgaria, vol. 2, 171-176.

11. Crudu, M., Deselnicu, V., Rosca, I., Sutiman, D., Cailean, A., Ghiga, M., Bocu, V., Boca N., Capac, D., Eco-friendly Tanning Agents to be Used in Leather Manufacture, CHEMPOR 10th International Chemical and Biological Engineering Conference, Proceedings, 498499, September 2008, Braga, Portugal.

12. Deselnicu, V., Arca, E., Badea, N., Maier, S.S., Deselnicu, D.C., Alternative Process for Tanning Leather, Leather and Footwear Journal, 2008, 8, 4, 25-34.

13. Pruneanu, M., Maier, S.S., Maier, V., Deselnicu, V., Mutlu, M.M., Gulumser, G., Bitlisli, B.O., Basaran, B., Adiguzel Zengin, A.C., Oligomeric Melamine-Formaldehyde Resin as Pre-tanning Agent, Proceedings of The 3rd ICAMS 2010, 16-18 September 2010, Bucharest, 113-118.

14. Pruneanu, M., Maier, S.S., Niculescu, O., Vitan, F., Deselnicu, V., Obtaining and Characterization of a Benzensulfonate 
Melamine-Formaldehyde Resin, with Applications in Leather and Fur Industry, Rev Chim, 2011, 62, 1, 60-63.

15. Albu, L., Popescu, M., Deselnicu, V., Albu, E. and Zainescu, G., Study and Practice on Alternative Eco-friendly Processes for Leather Manufacture, Leather and Footwear Journal, 2011, 11, 3, 211-220.

16. Bayramoglu, E.E., Unique Biocide for the Leather Industry: Essential Oil of Oregano, $J$ Am Leather Chem As, 2007, 102, 11, 347.

17. Bayramoglu, E.E., Gulumser, G., Karaboz, I., The Investigation of Antibacterial Activities of Some Essential Oils in Wet-blue Leather, Int J Nat Eng Sci, 2008, 2, 1, 33.

18. Niculescu, O., Leca, M., Moldovan, Z., Deselnicu, D.C., Obtaining and Characterizing a Product with Antifungal Properties Based on Essential Oils and Natural Waxes for Finishing Natural Leathers, Rev Chim (Bucharest), 2015, $66,11,1733-1736$.

19. Niculescu, O., Manta, A., Waxy Product for Finishing Natural Leather and Leather Items, Romanian Patent Application, OSIM A/00532/2013.

20. Niculescu, O., Manta, A., Product with Antifungal Properties for Finishing Natural Leather and Leather Items, Romanian Patent Application, OSIM A/00538/2013.

21. Stević, T., Berić, T., Šavikin, K., Soković, M., Gođevac, D., Dimkić, I., Stanković, S., Antifungal activity of selected essential oils against fungi isolated from medicinal plant, Ind Crops Prod, 2014, 55, 116-122.

22. Chirila, C., Crudu, M., Deselnicu, V., Comparative Study Regarding Resistence of Wet-white and Wet-blue Leather to the Growth of Fungi, Revista de Pielarie Incaltaminte (Leather and Footwear Journal), 2014, 14, 2, 107-120.

23. Chirila, C., Crudu, M., Deselnicu, V., Study Regarding the Resistance to the Growth of Fungi of Wet-white Leather Tanned with Titanium-Aluminum, Proceedings of The 5 th ICAMS 2014, 23-25 October 2014, Bucharest, Romania, 31-36.

24. Chirila, C., Deselnicu, V., Crudu, M., Study Regarding the Resistance of Wet-white Leather Organic Tanned to the Growth of
Fungi, Proceedings of The 5th ICAMS 2014, 23-25 October 2014, Bucharest, Romania, 37-42.

25. Berechet, M.D., Chirila, C., Deselnicu, V., Antifungal Activity of Some Essential Oils on Cotton Fabrics, Proceedings of The 6th ICAMS 2016, 20-23 October 2016, Bucharest, 197-202.

26. Berechet, M.D., Chirila, C., Deselnicu, V., Antifungal Activity of Thyme Essential Oil on Woolen Sheepskins, Proceedings of The 6th ICAMS 2016, 20-23 October 2016, Bucharest, 203-208.

27. Chirila, C., Berechet, M.D., Deselnicu, V., Thyme Essential Oil as Natural Leather Preservative against Fungi, Proceedings of The 6th ICAMS 2016, 20-23 October 2016, Bucharest, 227-232.

28. Stockman, G., Didato, D.T., Rangarajan, R., Alternative Solutions for Fungal Protection of Packaged Wet-blue, J Am Leather Chem As, 2006, 101, 7, 461.

29. Cadirci, B., Basaran, B., Bitlisli, B., Yasa, I., Aslan, A., Physical and Antimicrobial Characteristics of Aloe Vera Treated Split Suede Leather, J Am Leather Chem As, 2010, 105, 2, 34.

30. Cuadros, S., Manresa, M.A., Font, J., Bautista, M.E., Maldonado, F., Marsal, A., Alternative Fungicides: Comparisons with Conventional Chemicals, J Soc Leath Tech Ch, 2011, 95, 6, 263.

31. Sirvaityte, J., Siugzdaite, J., Valeika, V., Application of Commercial Essential Oils of Eucalyptus and Lavender as Natural Preservative for Leather Tanning Industry, Rev Chim (Bucharest), 2011, 62, 9, 884.

32. Sirvaityte, J., Siugzdaite, J., Valeika, V., Application of Essential Oils of Thyme as a Natural Preservative in Leather Tanning, Proc Estonian Acad Sci, 2012, 61, 3, 220.

33. Neffati, M., Sriti, J., Hamdaoui, G., Kchouk, M.E., Marzouk, B., Salinity Impact on Fruit Yield, Essential Oil Composition and Antioxidant Activities of Coriandrum sativum Fruit Extracts, Food Chem, 2011, 124, 221225.

34. Sreelatha, S., Padma, P.P., Umadevi, M., Protective Effects of Coriandrum sativum Extracts on Carbon Tetrachloride-induced Hepatotoxicity in Rats, Food Chem Toxicol, 2009, 47, 702-708. 
35. Zoubiri, S., Baaliouamer, A., Essential Oil Composition of Coriandrum sativum Seed Cultivated in Algeria as Food Grains Protectant, Food Chem, 2010, 122, 12261228.

36. Zamindar, N., Sadrarhami, M., Doudi, M., Antifungal activity of coriander (Coriandrum sativum L.) essential oil in tomato sauce, Journal of Food Measurement and Characterization, 2016, 10, 589, doi:10.1007/ s11694-016-9341-0

37. Ramadan, M., Mörsel, J.T., Oil Composition of Coriander (Coriandrum sativum L.) Fruitseeds, Eur Food Res Technol, 2002, 215, 204, doi:10.1007/s00217-002-0537-7

38. Pascal, J.D., Stanich, K., Benoit, G., Mazza, G., Antimicrobial Activity of Individual and Mixed Fractions of Dill, Cilantro, Coriander and Eucalyptus Essential Oils, Int J Food Microbiol, 2002, 74, 101-109.

39. Inouye, S., Takizawa, T., Yamaguchi, H., Antibacterial Activity of Essential Oils and Their Major Constitutents against Respiratory Tract Pathogens by Gaseous Contact, J Antimicrob Chemother, 2001, 47, 5, 565-573.
40. Dorman, H.J.D., Deans, S.G., Antimicrobial Agents from Plants: Antibacterial Activity of Plant Volatile Oils, J Appl Microbiol, 2000, 88, 308-316.

41. Sokovic, M., Glamoclija, J., Marin, P.D., Brkic, D., van Griensven, L.J.L.D., Antibacterial Effects of the Essential Oils of Commonly Consumed Medicinal Herbs Using an in vitro Model, Molecules, 2010, 15, 7532-7546.

42. Anwar, F., Sulman, M., Hussain, A.I., Saari, N., Iqbal, S., Rashid, U., Physicochemical Composition of Hydro-distilled Essential Oil from Coriander (Coriandrum sativum L.) Seeds Cultivated in Pakistan, J Med Plant Res, 2011, 5, 15, 3537-3544.

(C) 2017 by the author(s). Published by INCDTPICPI, Bucharest, RO. This is an open access article distributed under the terms and conditions of the Creative Commons Attribution license (http://creativecommons.org/licenses/by/4.0/). 